\title{
cmps
}

\section{The Ethnic Stacking in Africa Dataset: When leaders use ascriptive identity to build military loyalty}

Conflict Management and Peace Science

(C) The Author(s) 2021

(c) (i)

Article reuse guidelines: sagepub.com/journals-permissions DOI: $10.1177 / 07388942211044999$

journals.sagepub.com/home/cmp

\section{Kristen A. Harkness}

School of International Relations, University of St Andrews, UK

\begin{abstract}
Ethnicity has played a core role in the construction of African security institutions, with leaders often relying on coethnics to secure military loyalty. Such practices, termed ethnic stacking, likely have profound consequences for a range of important outcomes, from combat effectiveness to coup propensity to democratization. The Ethnic Stacking in Africa Dataset provides the first comprehensive data on the ethnic stacking practices of all African countries, from independence to 2018 (with $95.7 \%$ of leaders and $98.3 \%$ of country years recovered). This new data will allow scholars to better understand African militaries and their behavior and capabilities.
\end{abstract}

Ethnicity has long been central to the construction of security institutions, particularly in postcolonial states. Martial race doctrine strongly shaped colonial military and police recruitment practices, with groups considered too politically unreliable or rebellious barred from service, setting a precedent for widespread ethnic exclusion across Africa, the Middle East, and Southeast Asia (Ray, 2012: 561; Wilkinson, 2015: 42-52; Young, 1994: 105-106). Since decolonization, worried by the possibilities of coup attempts and ethnic insurgencies, many leaders have continued to rely on the recruitment and promotion of coethnics to control the military and ensure its loyalty. Such practices, termed ethnic stacking, range from ethnically manipulating the highest ranks of the command hierarchy to creating elite coethnic paramilitary units, to conditioning all service on shared ethnicity (see Decalo, 1989, 1998; Enloe, 1975, 1980; Goldsworthy, 1981; Horowitz, 1985).

As a widespread form of loyalty manipulation, ethnic stacking has profound consequences for a range of important political and social processes. Scholars have theorized that ethnic stacking prevents coups d'état and bolsters regime stability, enhancing the ability of dictators to entrench their rule and roll back liberalization (Decalo, 1998; Harkness, 2017; N'Diaye, 2001). Even where autocrats fall, ethnically stacked armies systematically block democratization efforts, as their fate and

\section{Corresponding author:}

Kristen A. Harkness, School of International Relations, University of St Andrews, Arts Building, The Scores, St Andrews, UK.

Email: kh8I@st-andrews.ac.uk 
continued access to military power and patronage is tied to the continuing rule of a coethnic leader (Bratton and van de Walle, 1997; Harkness, 2016, 2018). Excluding ethnic groups from such an important state institution as the military could also inspire mass unrest, from protests and riots to insurgency and terrorism, mirroring findings on how exclusion from executive power motivates ethnic rebellion (Cederman et al., 2010; Cederman et al., 2013; Roessler, 2011, 2016; Wimmer et al., 2009). Furthermore, ethnically and racially loyal security forces behave differently toward protestors and rebels hailing from out-groups, shaping human rights practices, surveillance, repression, and other repertoires of state violence. Meanwhile, promotion practices that privilege ethnic identity above merit probably undermine combat effectiveness, as other forms of coup proofing have (Pilster and Böhmelt, 2011; Talmadge, 2015). Yet ultimately, ethnically loyal forces may allow regimes to survive uprisings from below, as a growing literature suggests (Albrecht, 2015; Bellin, 2012; McLauchlin, 2010; McLauchlin and Morency-Laflamme, 2020; Morency-Laflamme, 2018).

Rich theoretical and case study research thus already emphasizes the numerous impacts of ethnic stacking on fundamental dynamics of state power, autocratization, democratization, rebellion, and violence. Yet we currently lack systematic data on ethnic practices within militaries, hampering our understanding of these effects by preventing statistical analysis and rigorous hypothesis testing. As an often relied upon pillar of regime security and strength, not controlling for ethnic stacking may also bias results in statistical analyses focused on other important outcomes such as the rule of law, patronage, corruption, and development.

The Ethnic Stacking in Africa Dataset (ESAD) begins to fill this crucial gap by focusing, as a first step, on the African continent-where countries tend to be highly ethnically diverse and where ethnic stacking has been central to the civil-military control strategies of many regimes. ESAD thereby contributes to a growing effort to collect fine-grained data on the composition and characteristics of security forces, including on counterbalancing (De Bruin, 2019), purges (Sudduth 2017; Sudduth, 2019), military participation in government (White, 2017), conscription (Margulies, 2018), and ethnic representation and group treatment. The latter includes Project Mars, which documents ethnic group representation among belligerents in conventional wars as well as pre-war discrimination and violence experienced at the hands of incumbent governments (Lyall, 2020: 153-157). Relatedly, Johnson and Thurber (2020) gathered data on ethnic group access to the military in the Middle East, coding whether groups are under- or over-represented compared with their population numbers in both the officer corps and rank-and-file. ${ }^{1}$

ESAD differs from these other data collection efforts based on ethnic representation or demography within military institutions. Ethnic stacking is an analytically distinct concept-neither synonymous with nor reducible to over-representation or discrimination - that requires a unique coding approach. First, the concept fundamentally hinges on "ethnic matching" between the head of state and their coercive institutions, which generates loyalty. When an ethnic group dominates the military but does not control executive power, very different dynamics result.

Second, relative ethnic group representation only weakly signals whether stacking has occurred. Sometimes the raw numbers do paint a clear picture of ethnic stacking, with the leader's coethnics dominating across the entire military (or at least the officer corps). This would be the case in apartheid era South Africa and Rhodesia, where black Africans were barred wholesale from the officer corps (Cawthra, 2003: 32-38; Johnson, 2015: 374). In other contexts, however, ethnic stacking works in much more subtle ways. In contemporary Kenya and Rwanda, for example, only the very top of the command hierarchy is controlled via ethnic loyalty, with often great care taken to cultivate inclusiveness at lower ranks (Hornsby, 2013: 712-713; Stubbs, 2015: 78). In other contexts, ethnic stacking is restricted to specialized military or paramilitary units, with much of the regular army left diverse. 
ESAD develops comprehensive data on ethnic stacking, as a leader-driven mechanism of securing military loyalty. ${ }^{2}$ The data cover all of Africa, including North Africa and the surrounding island states, from decolonization to 2018. For the overarching measure of ethnic stacking, $95.7 \%$ of leaders and $98.3 \%$ of country-years were recovered. The dataset also includes disaggregated measures to capture important dimensions of stacking: including whether stacking occurred in the regular military vs. paramilitary units, the extent to which stacking penetrated the command hierarchy of the army, and the types of ascriptive identity cleavages shaping stacking practices, including region. This data should be of great value to scholars of African civil-military relations, political violence, dictatorship, democratization, and ethnic politics.

In the remainder of the article, I first describe the data and its collection, including coding guidelines, methodology, sources, and conceptual issues. Special consideration is paid to the complexity of ethnic identity and the decision to code based on ethnic practices within military institutions rather than ethnic demography or a pre-existing schema of politically relevant ethnic groups. I then present summary data, including patterns across time, sub-regions, disaggregated practices, and in relation to leader survival. Of particular note, only $33.3 \%$ of African leaders have ethnically stacked their security institutions - a surprising finding given the continent's reputation for salient ethnic cleavages and neopatrimonial politics. Ethnic stacking varies substantially across subregions, with Central Africa constituting the worst offender, but has declined everywhere with increasing democratization. Indeed, autocracies are far more likely to ethnically stack than democracies $(50.7 \%$ of leaders vs. $24.1 \%$, or nearly $0 \%$ of more consolidated democracies). Leaders engaged in ethnic stacking also survive longer in office, especially those who maintain coethnic paramilitaries, rely on sub-ethnic cleavages to stack, and restrict their ethnic manipulations to only the highest ranks of the military.

Finally, I leverage the ESAD data to better understand the internal dynamics of autocracies. Ethnic stacking is positively correlated with both counterbalancing and personalized control over civilian institutions, and negatively correlated with ethnic inclusion in executive power-suggesting a package of complementary strategies that dictators draw on to consolidate power. Yet clumping all autocracies together masks important differences across regimes: while military juntas and personalist dictatorships engage in widespread stacking (73.5 and 51.4\% of leaders, respectively), single-party states and monarchies less frequently do so (24.3 and $16.7 \%)$. Sub-types of autocracies also have distinct preferences for how they ethnically stack. For example, military dictators often draw on regional identities, abhor paramilitaries, and tend to stack the entire officer corps but not the rank-and-file. On the other hand, when they ethnically stack, single-party states veer away from regional identity cleavages and only stack the highest ranks of the army, while also relying heavily on coethnic paramilitaries.

\section{Data collection, coding, and conceptual issues}

ESAD follows Chandra's minimal constructivist definition of ethnicity that understands ethnicity's core distinguishing feature as ascription-e.g. descent or a mythology of descent (2012: 59-60). I thus use "ethnicity" and "ethnic stacking" as broad terms that encompass the full range of ascriptive identities appropriate to a given context. This includes, for example, the very meaningful regional identities of Sahelian states, the clans and sub-clans of Somalia and Burundi, and the racial categories created by apartheid in South Africa and Rhodesia.

ESAD captures several important dimensions of ethnic stacking practices across Africa, including whether stacking occurred in military vs. paramilitary units, the extent of stacking within the command hierarchy and the type of ascriptive identity cleavage along which stacking occurred. The data is available in two formats: by leader-spell and by country-year. 
Leaders were initially identified using the Archigos data on political leaders from 1875 to 2004, which was then expanded to 2018 (Goemans et al., 2009). Most African countries decolonized between the late-1950s (Ghana, Guinea, and Sudan) and early 1960s, with the first leader recorded following independence. A small number of countries were never colonized (Ethiopia and Liberia), were subject to apartheid under white minority rule (South Africa and Rhodesia), or had unique semi-independent colonial arrangements in the early twentieth century (Egypt). For consistency, they enter the dataset around the same time as the other countries. ${ }^{3}$

Data collection followed best practices in building historically oriented replication databases (Lieberman, 2010). As a first stage, qualitative historical narratives were compiled for each leader, tracing how ascriptive identity informed both military and paramilitary recruitment practices. ${ }^{4}$ The narratives draw on a wide variety of primary and secondary sources in multiple languages (English, French, and Portuguese). The codebook cites over 400 individual sources, with many more having been consulted - including archival records and government documents, ${ }^{5}$ newspaper articles, reference books and other tertiary qualitative datasets, think tank reports, and scholarly accounts including historiographies, ethnographies, and sociological studies of African militaries. The codebook contains brief narratives for each leader, which serve as an important resource in their own right. Quantitative variables were then coded by leader and later converted to country-year data. All observations were hand-coded by the author, with guidelines and decisions noted transparently in the codebook.

The overarching variable Ethnic stacking indicates whether a leader engaged in any form of the practice. Coding decisions were based on qualitative understandings of recruitment practices, rather than numerical thresholds, for the two reasons already noted: first, ethnic stacking often occurs in ways not captured by numerical dominance, such as when only key command and control units are placed in the hands of coethnics or when the military itself is kept diverse but marginalized while coethnics dominate an elite paramilitary group; and second, fine-grained information on ethnic representation in African militaries is highly politically sensitive and not available with any degree of accuracy for many leaders. The missing data and bias issues would be staggering. The Ethnic stacking variable has four possible codings:

- Coded 1 if the leader selectively recruited coethnics (and possibly allied groups) into the officer corps of the military or into an elite presidential guard or other paramilitary unit. This practice also entails the purposeful exclusion of other identity groups from the military, including via purges, demotions, or declining to hire or promote on the basis of ascriptive identity. In Africa, in the vast majority of cases, ethnic stacking primarily occurs in land forces as navy and air forces are generally quite small (although there are exceptions).

- Coded 0 if, alternatively, the leader recruited officers from a diverse cross-section of society or other evidence was found that they did not purposefully engage in ethnic stacking (e.g. they were not intentionally excluding).

- Coded 0.5 if the leader changed strategies part way through their rule. Generally, a leader's entire tenure was coded as ethnically stacked or not owing to limitations in yearly information, unless specific evidence was found indicating a discrete change in practices. The date of change is noted in the narratives so that the time-series data could be accurately converted.

- Coded 999 if the country is considered ethnically homogenous. The data user can thus identify such countries and handle them appropriately according to their theoretical framework. In these contexts, ethnic stacking generally makes very little sense as a concept and including homogeneous countries could bias results or create unnecessary noise in the data. A country is considered ethnically homogenous if one group constitutes $95 \%$ or more of the 
population and there are no important regional divides. Such ethnically homogeneous countries in Africa are limited to Cape Verde, Lesotho, São Tomé and Príncipe, Seychelles, and Swaziland. Such a conservative approach is warranted given Africa's historical experience, which demonstrates that even fairly homogenous countries such as Rwanda and Burundi have repeatedly engaged in ethnic stacking by both minority and majority groups (Daley, 2006: 667-670; Lemarchand, 1989: 23; Uvin, 1999: 258).

For leaders engaging in ethnic stacking, further variables were coded to disaggregate their practices. ES_mil and ES_paramil are non-mutually exclusive bivariate indicators for whether stacking occurred in military or paramilitary units, respectively. The categorical variable, Extent of stacking, reflects how far down the military hierarchy stacking penetrated. Codings were based on the language of the source materials:

- Coded 0 if the leader did not ethnically stack the regular military.

- Coded 1 if ethnic stacking is described in terms of key command and control positions, the Generals, or the "elite," "higher," or "upper" ranks of the officer corps.

- Coded 2 if ethnic stacking is discussed as general dominance of the officer corps or as occurring among middle to lower ranked officers.

- Coded 3 if ethnic stacking is explicitly stated to extend to the rank-and-file.

Region, Ethnic, and Sub-ethnic comprise another set of non-mutually exclusive bivariate indicators that capture what kinds of ascriptive cleavages were leveraged to garner security force loyalty. Within complex, nested identity structures, leaders could draw on multiple levels simultaneously by, for example, staffing key command and control positions with individuals from the same clan, filling out the officer corps with members of their broader ethnic group, and recruiting rank-and-file soldiers from the same region. Codings were based on the identity groups mentioned by the underlying sources and should be treated as perceptions.

The Appendix contains brief narratives for the eight leaders of Uganda, including coding decisions for each of the above variables. Uganda is shown because of the diversity of its leaders' practices. While most stacked, the Baganda leaders that followed Idi Amin's overthrow tried to ethnically diversify the military. Both Amin and Milton Obote manipulated ethnicity down to the rank-and-file. Yoweri Museveni has only tampered with the highest ranks of the military command hierarchy while also relying on a coethnic presidential guard. Uganda's leaders have ranged widely in the types of cleavages they rely on to stack, from sub-ethnic groups to broad regional identities.

The leader-spell data further includes variables for the Tenure of the leader, measured as their duration in office in months, and for Leader ethnicity. The latter includes as detailed a description as could be found of the leader's ethnic identity. Where relevant and available, multiple layers of identity are recorded, including region, ethnic sub-groups and clans, as well as the primary ethnic group. This information was necessary to code ethnic stacking but should also be a useful resource for any scholar working on ethnic politics in Africa.

The country-year data contains a Transition variable, noting whether at least one leadership transition occurred in the year of observation. There are also two variants of each country-year variable to reflect the fluidity of such transition years: for example, Ethnic stacking_begin and Ethnic stacking_majority. The former codes ethnic stacking based on the leader who ruled on 1 January of the observation year while the latter reflects who ruled for the majority of the year. 
Additionally, the variable New stacking was coded to capture the initial throes of building an ethnic army. It was coded 1 if, in that year or the two previous years, ethnic stacking practices began either (1) where previously the military had been recruited diversely or (2) where ethnic stacking had occurred along a different identity basis (e.g. the groups being selectively recruited changed). For the first three years of independence, New stacking was coded 1 if the leader stacked and the late colonial officer corps did not already match their ethnic identity. ${ }^{6}$ Thus, rather than tracking a country's first experience with ethnic stacking, this variable indicates whether the leader was beginning to construct an ethnic army, having not inherited one already matching their ascriptive identity.

A number of important conceptual issues arose throughout the data collection effort. Most fundamentally, what counts as ethnic stacking-especially where one group would dominate the military even given fair recruitment standards? Again, ethnic stacking is more than just numerical preponderance and certain ethnic stacking strategies do not require dominance by weight of numbers, such as stacking particular elite units or the higher echelons of the officer corps. Rather, ethnic stacking is considered a set of practices that intentionally condition military recruitment and promotion on ethnic identity in order to exert control over the armed forces. This involves (1) exclusion of at least some non-coethnic groups from at least some units or positions and (2) intentional recruitment of coethnics, and potentially members of allied ethnic groups, into these same units or positions. Even in countries where one group would naturally form a majoritysuch as Rwanda or Burundi where Hutu constitute $85 \%$ or more of the population-if ethnic stacking is occurring, we should still find evidence that other groups are being intentionally excluded.

Reliability of source materials can also pose a challenge. In highly ethnically politicized societies, where inclusion and exclusion within the security forces carry significant practical and normative meaning, both the government and outsiders have incentives to misrepresent the ethnic composition of the military. Codings thus hew as closely as possible to the qualitative understandings of generally reliable sources, including scholarly accounts, print journalism from outside the country in question (this is particularly important under dictatorships), and archived internal documents. Indeed, the British and French have routinely sent training and assistance missions to African countries as well as directly seconding officers into their command hierarchies. These foreign officers report back to their home country, creating an archived paper trail of military policy and practices, even when the host state may not itself have preserved or released records.

In very rare cases of conflicting information, resolution followed an historiographical approach with additional research conducted until the preponderance of evidence enabled judgement. Usually the origin of such conflicts became apparent when disaggregating ethnic stacking as a practice. For example, secondary sources on Rwanda sometimes differ on their assessment as to whether President Paul Kagame has ethnically stacked the army. Detailed studies on the post-genocide military integration process shed light on why such conflicting interpretations have arisen. After capturing power, Kagame's Tutsi-led regime did successfully reintegrate Hutu into the national military, including at higher ranks of the officer corps. However, the most senior leadership and vital command positions within the army have been kept in the hands of former rebel Tutsi officers (Jowell, 2014: 279-289). Rwanda under Kagame was thus coded as ethnically stacked, but only to a limited degree $($ Extent $=1)$.

Nor is it always straightforward who the leader's coethnics are. In many African countries, ethnic identity is highly complex with mixed heritage and layered group identities common. Regions, ethnic groups, sub-ethnic groups, and clans have all become important political identities shaping military recruitment. For example, sub-groups of the Fang in Gabon have been recruited 
differentially into the security forces with the Estuary Fang favored in the Gendarmerie under Leon Mba (Decalo, 1998: 133). Clan identities have routinely structured military recruitment in Somalia, with the current national army drawn predominantly from three sub-clans of the Hawiye (Robinson, 2016). Region has shaped ethnic stacking in many Sahelian states where important north-south divides overlap ethnic, religious, linguistic, and racial cleavages. Colonialism reinforced these regional divides through separate administration and development policies that gave educational and economic advantages to the south (Harkness, 2018: 38). In 1960s Benin, both Hubert Maga and Christophe Soglo drew on regional coalitions, northern vs. southern, to stack the ranks of the officer corps (Decalo, 1973: 458-462; Horowitz, 1985: 451-456). The mixed heritage of some African leaders complicates even further this portfolio of possible, layered identities that could be drawn on when stacking the military.

Appropriately handling this ethnic complexity requires careful consideration. One could rely on a pre-existing framework of which identities matter in a given country at a given point in time-such as that provided by the Ethnic Power Relations (EPR) dataset (Vogt et al., 2015). This would have the advantage of compatibility with the EPR family, but at a high cost as their categorizations of politically relevant identity groups often fail to account for which groups matter specifically within military institutions. For example, EPR considers ethnicity "irrelevant" in Somalia, which overlooks the clan dynamics that often shape security forces. Rather, I relied on the underlying source materials to indicate which identities were being activated by the leader in military recruitment and promotion practices. This follows Chandra's constructivist approach of distinguishing between ethnic demography (or structure) and ethnic practice, which recognizes the importance of context in conditioning which ethnic categories become salient and which particular ethnic identities individuals choose to emphasize and act upon at a given time (Chandra, 2012: 51-60).

Coethnics are thus considered members of any group or sub-group that match any of the leader's claimed identities. This can include religion, ethnicity, race, tribe, clan, region, or other kinship networks. This approach can accommodate leaders with mixed identities and is flexible enough to change over time as different cleavages gain or decline in importance. This is especially important as leaders widen or narrow their ethnic recruitment practices. For example, in Sierra Leone, Siaka Stevens at first stacked the military with northerners but later confined his ethnic stacking to the Limba (Cox, 1976: 106-107; Davies, 2000: 352-353; Horowitz, 1985: 477-479; Kandeh, 1992: 94). Similarly, in Burundi, Pierre Buyoya progressively narrowed the ethnic basis of the military from all Tutsi to the Tutsi-Hima to the Rotovu, Matana, and Vyanda clans (Lemarchand, 1989: 23; Ngaruko and Nkurunziza, 2000: 382). On the other hand, when Michel Djotodia took power in the Central African Republic through a power-sharing peace treaty, he switched the main cleavage of stacking practices from ethnic identity to a broader regional and religious identity-northern Muslims - to draw on the support of a coalition of ethnic groups. My approach counts all of these periods as ethnic stacking, while a rigid ethnic classification framework would not. Furthermore, the stacking cleavage variables (Region, Ethnic, Subethnic) preserve much of this nuance, allowing researchers to analyze when and why certain types of cleavages become salient within the military rather than prejudging the political relevance of identities.

Finally, while the vast majority of shifts in ethnic stacking followed a change in leadership, occasionally a leader did fundamentally alter their practices during their tenure, from engaging in ethnic stacking to recruiting diversely, or vice versa. Eight such shifts were detected (see Table 1) which, on initial reflection, may seem unrealistically low. Yet recall that the New stacking variable already captures a large number of shifts from diverse recruitment to ethnic stacking, if they occurred in the first few years of a leader's tenure. Often fuzzy underlying information prevented more fine-grained coding on exactly when these early shifts began. 
Table I. Within-leader shifts between ethnic stacking and diverse recruitment.

\begin{tabular}{llllll}
\hline Country & Leader & Rule & Year & Direction & Reason \\
\hline Angola & Dos Santos & $1979-2017$ & 1992 & $1 \rightarrow 0$ & Peace agreement \\
Ghana & Nkrumah & $1957-1966$ & 1963 & $0 \rightarrow 1$ & Failed assassination/coup \\
Ghana & Rawlings & $1981-2001$ & 1987 & $1 \rightarrow 0$ & Professionalization \\
Guinea-Bissau & Vieira & $1980-1999$ & 1985 & $0 \rightarrow 1$ & Failed assassination/coup \\
Guinea-Bissau & Vieira & $2005-2009$ & 2008 & $0 \rightarrow 1$ & Failed assassination/coup \\
Malawi & Banda & $1964-1994$ & 1992 & $1 \rightarrow 0$ & Mass protests \\
Mauritania & Ould Taya & $1984-2005$ & 1989 & $0 \rightarrow 1$ & Ethnic rebellion \\
Zimbabwe & Mugabe & $1979-2017$ & 1982 & $0 \rightarrow 1$ & Breakdown of former rebel alliance
\end{tabular}

Note: Direction $0 \rightarrow \mathrm{I}$ indicates a shift from diverse recruitment to ethnic stacking and $\mathrm{I} \rightarrow 0$ the opposite.

We should also expect highly static ethnic stacking practices under a given leader for two reasons: First, ethnic stacking is fundamentally incompatible with consolidated democracy. Ethnic armies have also notoriously blocked democratization efforts across Africa (Harkness, 2015). After struggling to overcome such legacies, or never having had stacked security institutions in the first place, democratic leaders should consistently maintain diverse armies. Dictators, on the other hand, intentionally design their coercive institutions - at the beginning of their rule-to counter the perceived dominant threat to their power. These choices then get "locked in", consistent with well-established understandings of institutional path-dependency (Greitens, 2016: 30-36). Indeed, the shifts in ethnic stacking noted in Table 1 almost always followed discrete upheavals that meaningfully and rapidly impacted leaders' threat perceptions while simultaneously unsettling institutions, creating space for change. These include failed assassination and coup attempts, outbreaks of rebellion, peace agreements, and regime-threatening mass protests.

Kwame Nkrumah of Ghana, for instance, initially emphasized merit, diversity, and correcting historic ethnic imbalances in the army (Ibid 258-259). Two assassination attempts in the mid-1960s then radically changed his practices: blaming the attempts on Ewe and Ga officers, Nkrumah began ethnically manipulating the military, including constructing an elite counter-intelligence unit dominated by coethnics (Ibid: 264). Hastings Banda, who ruled Malawi for 30 years, changed practices in the other direction and largely against his own wishes. Mass antiregime protests in 1992 compelled Banda to deploy the Malawi Young Pioneers, a Chewa stacked paramilitary unit, who then engaged in widespread repression and violence against dissidents. By December, junior officers and rank-and-file soldiers sided with the protestors, disarmed the Young Pioneers, and demanded the end of Chewa privilege in the higher ranks of the officer corps. Banda was forced to concede the destruction of his paramilitary forces and the complete unstacking of the regular military, which paved the way for democratizing elections (Chirambo, 2004: 147-157).

In its current form, the data has important limitations. First, it does not provide group-level measures, nor should it be used to infer demographic representativeness. Second, the data does not capture within-leader temporal shifts in either the ascriptive cleavages used to stack or their extent down the military hierarchy. Many leaders, sometimes even whole countries, are fairly static in these practices. Nigerian leaders have routinely relied on northern Hausa-Fulani generals, while Mauritanian leaders almost always selectively recruit their officer corps from the White Maure identity group (see online codebook). However, as previously noted, some dictators progressively narrowed the ethnic basis of the military while in power. In addition to Siaka Stevens and Pierre Buyoya, Horowitz also identifies such military ethnic attritional dynamics under Idi Amin 
of Uganda and Michel Micombero of Burundi (Horowitz, 1985: 496-500). Systematically gathering this information constitutes an important future expansion of the data.

\section{Summary statistics and trends}

Table 2 summarizes the final codings for the Ethnic stacking variable. Out of a total of 393 leaders, $95.7 \%$ were successfully coded with $98.3 \%$ of country-years recovered (2899 of 2950). Every effort was made to maximize data recovery, thereby minimizing potential biases from skewed information availability, such as those due to country size, length of leader tenure, or time. This should reassure users of the data's reliability and validity.

Only $33.3 \%$ of African leaders have ethnically stacked their security institutions, while $51.9 \%$ have maintained diverse militaries-perhaps a surprising finding given Africa's reputation for salient ethnic divides and neopatrimonialism. In part, this reflects that ethnicity is not actually a driving force in the politics of many African countries. No leader has engaged in ethnic stacking in Botswana, Burkina Faso, Egypt, Eritrea, Ethiopia, Mali, Mauritius, Morocco, Mozambique, Namibia, Senegal, Tanzania, Tunisia, or Zambia. When examining the country-year data, however, the rates of ethnic stacking rise substantially, with $46.8 \%$ of years coded positively. This results from the higher average tenure in office of leaders who ethnically stack their armies: 113.8 months, compared with 71.5 months for those who do not (see Figure 1).

The relatively modest rate of ethnic stacking also stems from important changes over time, particularly increasing rates of democratization across the continent. Figure 2 shows the proportion of African leaders that have ethnically stacked their militaries compared with the percentage of countries classified as democratic. ${ }^{7}$ Rates of ethnic stacking began at around $50 \%$ of leaders as African countries became independent, from the 1940s to the early 1960s. These rates quickly climbed to $60-70 \%$ of leaders throughout the 1970s and 1980s and then progressively fell from 1989 to the present-with around $35 \%$ of current African leaders engaged in ethnic stacking. These trends closely track levels of democracy across the continent, with the contemporary decline in ethnic stacking coinciding with the third wave of democratization.

Figure 3 breaks down patterns of ethnic stacking by sub-region. Central Africa is by far the worst offender, with $100 \%$ of leaders ethnically stacking in the 1980 s and, despite some improvement, $70 \%$ still doing so today. On the other hand, West Africa and Southern Africa have witnessed large declines in ethnic manipulation of the military, from around 60\% in the late 1980s to $20 \%$ or less today. Indeed, Southern Africa experienced exceptionally high rates of stacking during the apartheid era, when both Rhodesia and South Africa recruited exclusively white officer

Table 2. Summary of ethnic stacking codings.

\begin{tabular}{lllllll}
\hline & & \multicolumn{2}{l}{ Leader-spell } & & \multicolumn{2}{l}{ Country-year } \\
& & Count & Percentage & & Count & Percentage \\
\hline No ethnic stacking & 0 & 204 & 51.9 & & 1282 & 43.5 \\
Ethnic stacking & 1 & 131 & 33.3 & & 1382 & 46.8 \\
Change in practice & 0.5 & 8 & 2.0 & & \\
Homogenous society & 999 & 33 & 8.4 & & 235 & 8.0 \\
Missing & na & 17 & 4.3 & & 51 & 1.7 \\
recovery rate & & $95.7 \%$ & & & $98.3 \%$ & \\
\hline
\end{tabular}




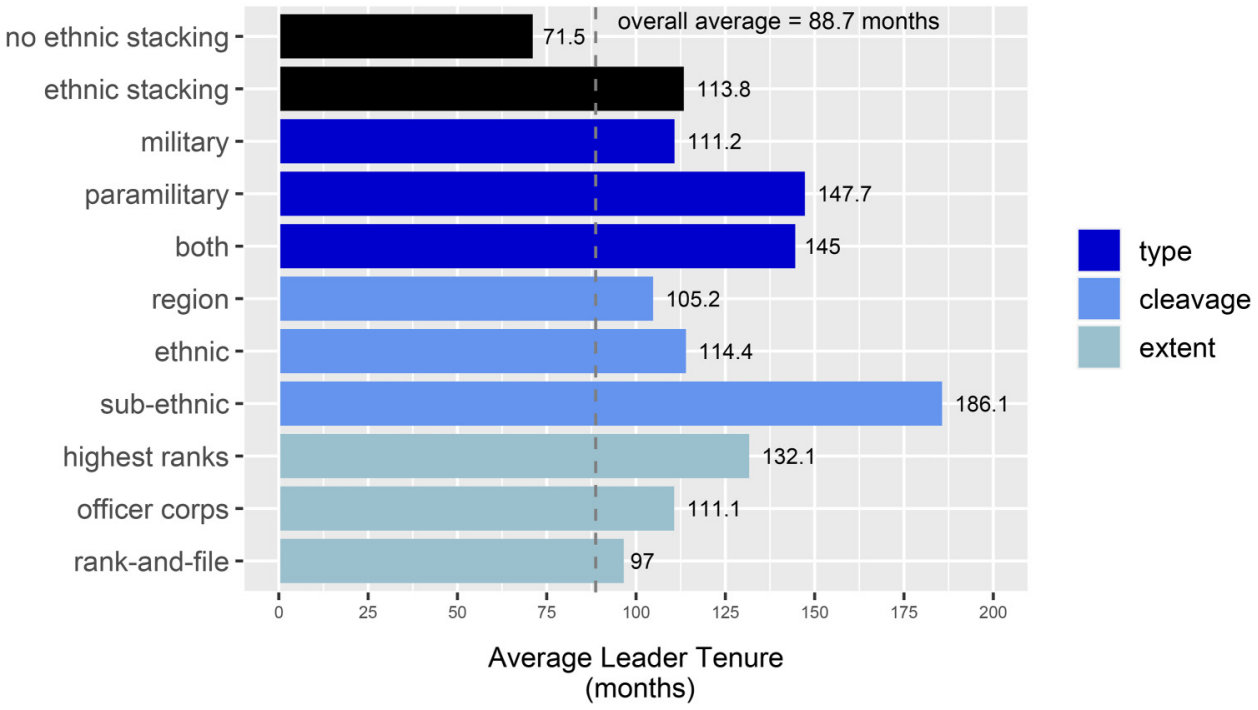

Figure I. Leader tenure by ethnic stacking practices.

corps' and the Portuguese had yet to decolonize. Military integration then became a core component of transitions to majority rule or peace treaties in Angola, Mozambique, Namibia, and South Africa -leaving a legacy of diverse armies in those countries (Colleo, 1991; Mashike, 2007; Preston, 1997; Vines, 2013: 379-380). East Africa represents the middle ground, with ethnic stacking reaching a high of $75 \%$ in the early 1970 s and incrementally declining to $40 \%$ today.

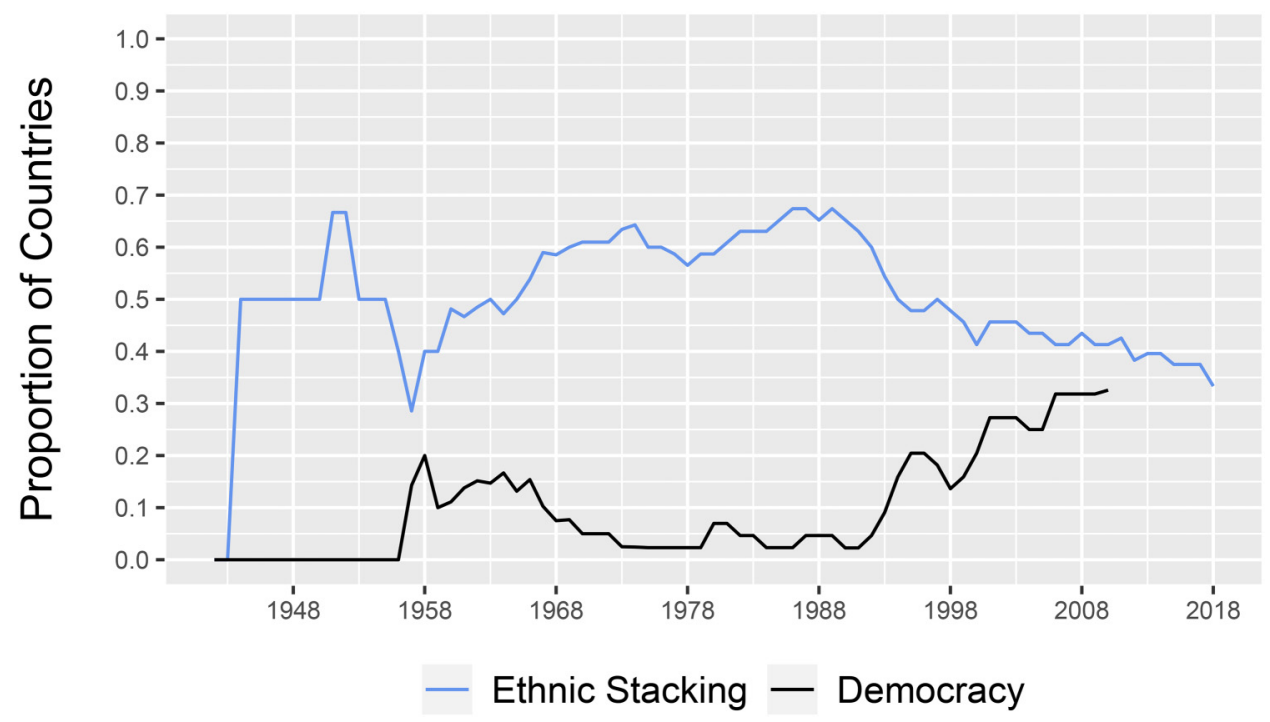

Figure 2. Ethnic stacking and democracy over time. 


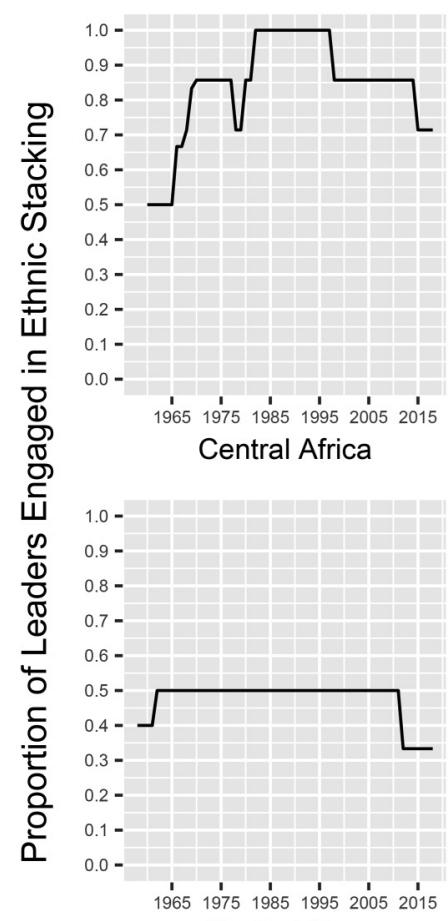

North Africa
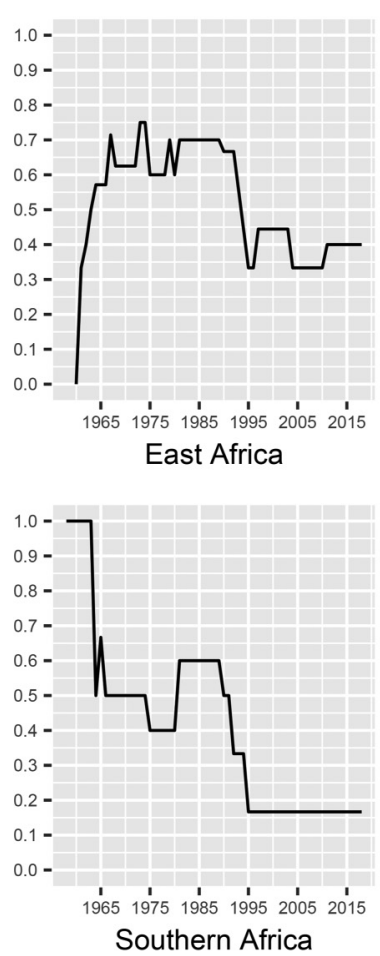
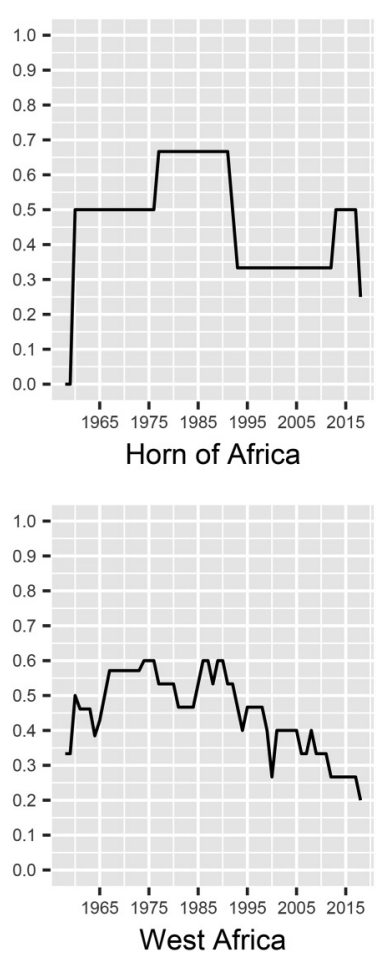

Figure 3. Ethnic stacking by sub-region over time.

Table 3 presents descriptive data on the disaggregated ethnic stacking variables. Notably, most stacking occurs in regular militaries. Even where leaders construct ethnically stacked paramilitary units, in the vast majority of cases (49 of 55) they still stack the military. One exception was President Félix Houphouet-Boigny of Côte d'Ivoire. While encouraging diversity in the army through a system of ethnic quotas, he created a 3000-man strong presidential guard recruited exclusively from his own Baoule group (N'Diaye, 2005: 97).

Among leaders who stacked the regular military, the extent of that stacking varied considerably: while $25.6 \%$ only recruited coethnics into the highest ranks of the officer corps, $34.6 \%$ stacked the entire officer corps, and $33.1 \%$ manipulated ethnicity down to the rank-and-file (with $6.8 \%$ missing sufficient information to code). While stacking almost always involved the leader's broad ethnic group (89.9\% of cases), many also relied on regional identity $(39.6 \%)$ or sub-ethnic group identity $(15.1 \%)$ as a basis for loyalty.

How leaders ethnically stack also shapes their ability to stay in power (see Figure 1). Leaders that create and personally control coethnic paramilitary units ruled, on average, for 147.7 months compared with 111.2 months for those who only stack the military and 71.5 months for those who refrain from stacking altogether. Leaders who leverage sub-ethnic cleavages to stack also survive significantly longer than others-an impressive average of 186.1 months. Perhaps counterintuitively, ethnic stacking most successfully protects leaders when they deploy it minimally: leaders ruled for an average of 132.1 months when they only ethnically manipulated the highest ranks of the military, compared with 111.1 months when stacking permeated the whole officer corps, and only 97.0 months when it extended to the rank-and-file. 
Table 3. Disaggregating ethnic stacking practices.

\begin{tabular}{|c|c|c|c|c|c|c|}
\hline & \multicolumn{3}{|c|}{ Leader-spell } & \multicolumn{3}{|c|}{ Country-year } \\
\hline & Count & $\begin{array}{l}\text { Percentage } \\
\text { of total }\end{array}$ & $\begin{array}{l}\text { Percentage } \\
\text { stacked }\end{array}$ & Count & $\begin{array}{l}\text { Percentage } \\
\text { of total }\end{array}$ & $\begin{array}{l}\text { Percentage } \\
\text { stacked }\end{array}$ \\
\hline \multicolumn{7}{|l|}{ Type of stacking } \\
\hline Military & 133 & 33.8 & 95.7 & 1303 & 44.2 & 94.3 \\
\hline Paramilitary & 55 & 14.0 & 39.6 & 705 & 23.9 & 51.0 \\
\hline Both & 49 & 12.5 & 35.3 & 626 & 21.2 & 45.3 \\
\hline \multicolumn{7}{|l|}{ Cleavage of stacking } \\
\hline Region & 55 & 14.0 & 39.6 & 540 & 18.3 & 39.1 \\
\hline Ethnic & 125 & 31.8 & 89.9 & 1246 & 42.2 & 90.2 \\
\hline Sub-ethnic & 21 & 5.3 & I5.I & 327 & II.I & 23.7 \\
\hline \multicolumn{7}{|l|}{ Extent of military stacking } \\
\hline Only highest ranks & 34 & 8.7 & 25.6 & 383 & 13.0 & 29.4 \\
\hline All officer corps & 46 & 11.7 & 34.6 & 444 & 15.1 & 34.1 \\
\hline And rank-and-file & 44 & 11.2 & 33.1 & 394 & 13.4 & 30.2 \\
\hline New stacking & & & & 156 & 5.3 & 11.3 \\
\hline
\end{tabular}

Note: Leaders who switched practices are included in the leader-spell counts, based on the period in which they stacked. Neither the subcategories for type of stacking nor cleavage of stacking are mutually exclusive. For the extent of stacking, the percentages are restricted to military stacking. Insufficient information was available to code the extent of stacking for $6.8 \%$ of leaders who engaged in some degree of military stacking.

\section{Ethnic stacking and autocratic power consolidation}

As suggested by the earlier comparison with democratization trends, dictators are far more likely to leverage coethnicity to control the military (see Table 4). Following the Geddes, Wright \& Frantz (GWF) regime type classifications (2014), 50.7\% of autocrats have ethnically stacked their security forces while only $24.1 \%$ of democrats have ( $56.5 \%$ vs. $22.9 \%$ of country-years). An even more dramatic distinction emerges when using the Varieties of Democracy polyarchy index to identify

Table 4. Ethnic stacking by regime type.

\begin{tabular}{|c|c|c|c|c|}
\hline & \multicolumn{2}{|c|}{ By leader } & \multicolumn{2}{|c|}{ By country year } \\
\hline & $n$ & Percentage stacked & $n$ & Percentage stacked \\
\hline Electoral democracies (Vdem) & 57 & 0 & 449 & 1.8 \\
\hline Democracies (GWF) & 54 & 24.1 & 271 & 22.9 \\
\hline Autocracies (GWF) & 213 & 50.7 & 1917 & 56.5 \\
\hline Military & 34 & 73.5 & 81 & 90.1 \\
\hline Monarchy & 6 & 16.7 & 112 & 17.0 \\
\hline Party & 37 & 24.3 & 588 & 31.0 \\
\hline Personal & 70 & 51.4 & 669 & 70.3 \\
\hline
\end{tabular}

Note: Leaders are coded as electoral democracies if they score 0.5 or above on the Vdem polyarchy index for the entirety of their tenure ( 0.5 is also used as the threshold for the country-year measure). The correlation between the Vdem and GWF measures of democracy is 0.48 by leader. The small number of country years where electoral democracies ethnically stacked were all by leaders who sometimes fell above and sometimes below this threshold for democracy. 
democratic leaders (Coppedge et al., 2019): almost no ethnic stacking occurs under leaders of more consolidated electoral democracies (only $1.8 \%$ of country-years).

This suggests that ethnic stacking is largely a tool of autocratic power consolidation. Dictators design coercive and other institutions based on perceived threats from both rival elites and the excluded masses (Greitens, 2016: 11; Svolik, 2012a, 2012b: 3-5). They can draw on a panoply of strategies to buffer against such threats, including but not limited to ethnic stacking. Autocrats also stabilize their rule by strategically coopting or excluding rival ethnic groups from executive power, counterbalancing, exerting personal control over civilian institutions, and institutionalizing elite power-sharing.

Each of these strategies, however, entails trade-offs for the dictator. Ethnic stacking encourages security force loyalty and decreases coup risk by currying in-group favoritism, linking patronage opportunities to shared ethnicity, and binding soldiers to the fate of their leader (Harkness, 2018: 43; Hassan, 2017). Yet ethnic exclusion from important state institutions, including potentially the military, creates inequality and group grievances that can motivate rebellion (Cederman et al., 2013: 57-92). Ethnic power sharing-or the accommodation of ethnic strongmen into central executive institutions and patronage structures-coopts groups and enhances the state's intelligence capacity to thwart mass uprisings. However, it simultaneously increases the threat capabilities of rival ethnic elites, who can now seize power from the inside (Roessler, 2016: 16-20, 9699).

Counterbalancing diminishes the likelihood of successful coups by creating paramilitary units with divergent organizational interests, tied to the survival of the leader, who will actively intervene and fight off the attempt. Yet counterbalancing also hinders battlefield effectiveness and demoralizes ordinary soldiers, making them less likely to stave off threats from below, including both rebellions and mass protests (DeBruin, 2020: 4-10).

Dictators also exert personal control over civilian institutions, which partially balances the threat posed by distrusted militaries. Dominant autocratic political parties co-opt elites and mobilize mass support by distributing benefits directly to supporters via party membership (Geddes et al., 2018: 101-105). Strong parties, however, become a threat in their own right—perhaps one day deciding that leadership change is past due. Finally, routinized power-sharing (or autocratic institutionalization) placates other elites and smoothes over turbulence within the dictator's inner circle. Yet only weak dictators tend to bind their hands so tightly, while stronger autocrats seek less restrictive tactics of control (Meng, 2020: 34-35).

Are these five autocratic power consolidation strategies systematically linked to one another? Meant to provoke intriguing questions and future avenues for research, Table 5 provides basic correlations ${ }^{8}$ between measures of ethnic stacking, ethnic inclusion in executive power (EPR inclusion), ${ }^{9}$ counterbalancing, ${ }^{10}$ civilian personalism, ${ }^{11}$ and civilian institutionalism. ${ }^{12}$ The statistically significant positive coefficients (or nearly so) between ethnic stacking, counterbalancing, and civilian personalism suggest that they comprise complementary strategies, rather than substitutes. Leaders that counter-balanced were more likely to ethnically stack, moving from a predicted probability of $41.7 \%$ to $60.0 \%$. The other relationships were weaker, with a shift from the mean to one standard deviation higher in the civilian personalism index increasing the expected probability of ethnic stacking and counterbalancing by, respectively, 6.1 and 8.0 percentage points.

Ethnic stacking is also strongly negatively correlated with ethnic group inclusion in executive state power. This is unsurprising, especially given EPR coding guidelines which define access to power in terms of: "the presidency, the cabinet, and senior posts in the administration in democratic regimes; the army command in military dictatorships; or the ruling party leadership in one-party states." ${ }^{13}$ Observed ethnic stacking thus shapes EPR group codings, if only partially and only in 
Table 5. Correlation matrix of autocratic power consolidation strategies.

\begin{tabular}{llllll}
\hline & Ethnic stacking & EPR inclusion & Counter-balancing & Personalism & Institutionalism \\
\hline Ethnic stacking & $\mathrm{I}$ & $-1.0700^{* *}$ & $0.7538^{\dagger}$ & 0.9738 & 0.5806 \\
EPR inclusion & & $\mathrm{I}$ & 0.2018 & 0.1322 & 0.0372 \\
Counterbalancing & & & $\mathrm{I}$ & $3.5445^{*}$ & 0.4638 \\
Civilian personalism & & & $\mathrm{I}$ & -0.0434 \\
$\quad$ Civilian & & & & $\mathrm{I}$ \\
$\quad$ institutionalism & & & & & \\
\hline
\end{tabular}

Note: The sample of autocratic regimes excludes the Vdem electoral democracies. Correlations were generated using logit models when at least one of the variables was dichotomous, and otherwise with an ordinary least squares model. The correlations between ethnic stacking/Ethnic Power Relations (EPR) inclusion and civilian personalism are nearly significant with $p$-values of $0.134 / 0.107$.

${ }^{* * *} \mathrm{P} \leq 0.001,{ }^{* *} \mathrm{P} \leq 0.01,{ }^{*} \mathrm{P} \leq 0.05,{ }^{\dagger} \mathrm{P} \leq 0.10$.

some regime types. Intriguingly, however, even highly inclusive regimes still frequently practice ethnic stacking, especially within autocracies. Figure 4 sorts governments into five progressive levels of EPR inclusiveness and shows the percentage of country-years coded with ethnically stacked security forces for each bin. High levels of ethnopolitical exclusion (under $20 \%$ of the population included) result in stacking over $84.5 \%$ of the time. Yet even the most inclusive

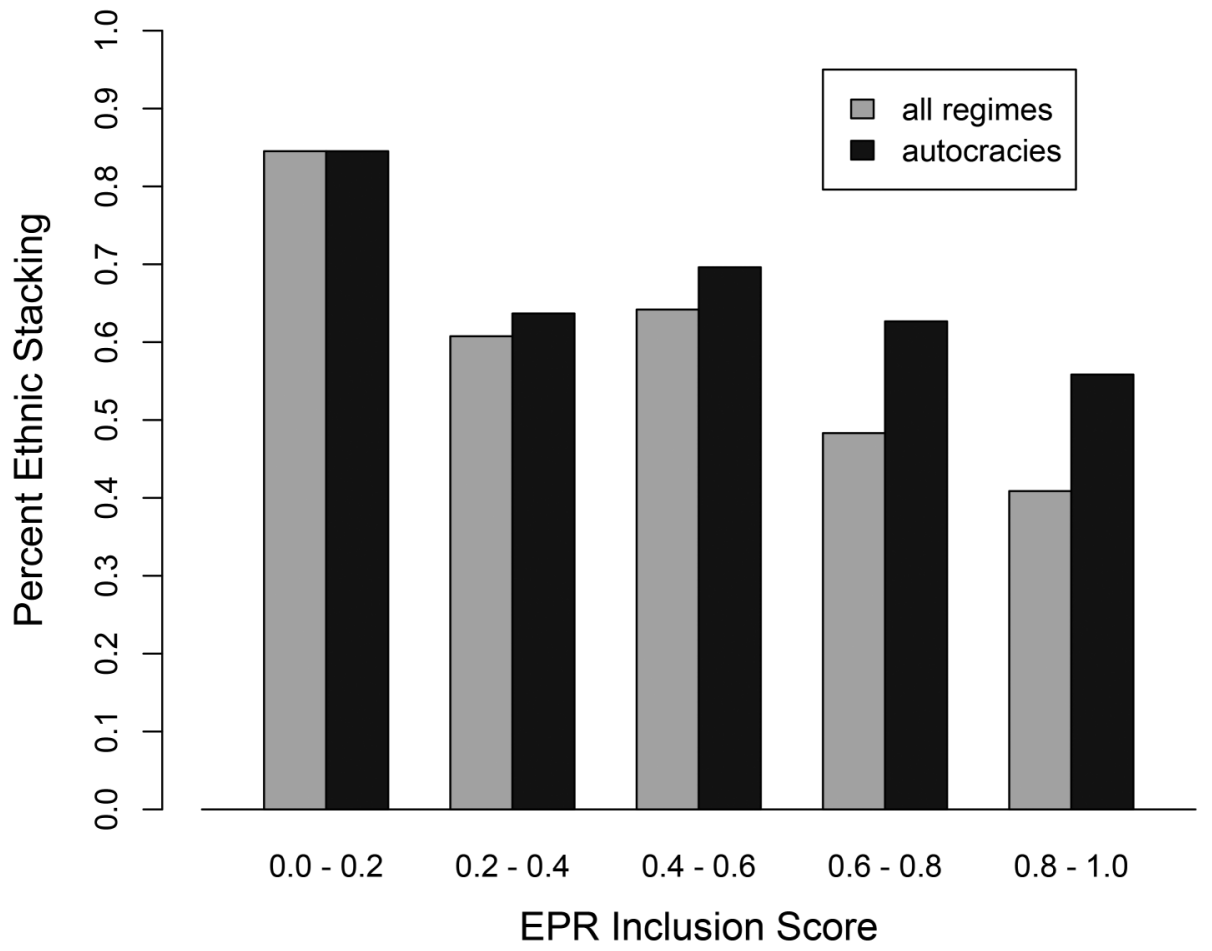

Figure 4. Executive power inclusion and ethnic stacking in security forces. 
governments still ethnically stack their militaries in $40.9 \%$ of country-years_-growing to $55.8 \%$ in autocracies. Ethnic cooptation in civilian executive institutions thus often coexists with exclusion from security forces. Together, these preliminary descriptive findings suggest that dictators are making complex choices across state institutions and combining power consolidation strategies in ways that warrant further exploration.

Turning to the disaggregated ethnic stacking data, meaningful differences emerge across subtypes of autocracies, both in whether they ethnically stack and how they do so. While the GWF typology of autocratic regime types has been critiqued-especially for the difficult classification judgments involved and the pervasiveness of hybridity (see Svolik, 2012b: 28-29)—it nonetheless captures important distinctions between ideal-type dictatorships originating in military juntas, grounded in single-party rule, or built largely around personal control. The following analysis excludes hybrid categorizations, focusing on leaders that were classified as meeting only one ideal type.

Military juntas are by far the most likely to stack (73.5\%), followed by personalist dictatorships (51.4\%), single-party states (24.3\%), and then monarchies (16.7\%) (see Table 4). Monarchies and single-party states arguably employ alternative mechanisms of ensuring their rule and building popular legitimacy. Well-developed party systems reduce the need for autocrats to engage in harsh repression or rely as heavily on their security forces for survival (Svolik, 2012b: 162195). This diminution of the threat environment, in turn, alleviates pressures to build up and manipulate coercive institutions, including through such measures as ethnic stacking and counterbalancing.

Analyzing the type of ethnic stacking, the cleavages shaping it, and its penetration down the military hierarchy across the sub-types of autocracy also reveals interesting patterns (see Figure 5). To better illustrate this variance in practices, all calculated percentages are conditional on leaders engaging in some form of ethnic stacking (e.g. the denominator is the number of leaders within a sub-type of autocracy who ethnically stacked). Data for monarchies is not included as only one monarch, King Idris of Libya, engaged in stacking. ${ }^{14}$

While personalist dictators commonly rely on ethnically stacked paramilitary units (55.6\%), military dictatorships do not (only $8.0 \%$ ). This is consistent with militaries' general abhorrence for paramilitaries as unwanted competitors, which juntas often disband after seizing power. Although single-party states less commonly engage in ethnic stacking, when they do, they lean heavily on paramilitaries $(66.7 \%)$. This perhaps stems from the widespread creation of party militias in these autocracies that, once the leader turns to ethnicity as a mechanism for loyalty, also become ethnicized.

When leaders ethnically stack, regardless of regime type, they almost always depend on their core ethnic group in some capacity. Exceptions tend to be leaders from very small ethnic groups that must leverage broader, usually regional, coalitions. For example, President Hilla Limann was from the northern Sissala ethnic group who only comprise around $1 \%$ of Ghana's population. Popularly elected but feeling threatened by an inherited Ewe-dominated army, and presumably without many Sissala in the military, he organized a counter-coup unit recruited from northern enlisted soldiers while also moving northerners into key command and control positions (Baynham, 1985: 638-639). Indeed, regional cleavages often shape ethnic stacking practices, although party regimes rely on them less than half as frequently as other autocracies $(22.2 \%$ vs. around 50\%). Notably, military regimes have not drawn on sub-ethnic cleavages to stack (0\%), while party and personal regimes sometimes do (11.1 and $16.7 \%$, respectively).

Analyzing the extent of stacking also reveals strong preferences by regime type. Party regimes are, by far, the most likely to constrain stacking to the highest echelons of the officer corps (44\% vs. 


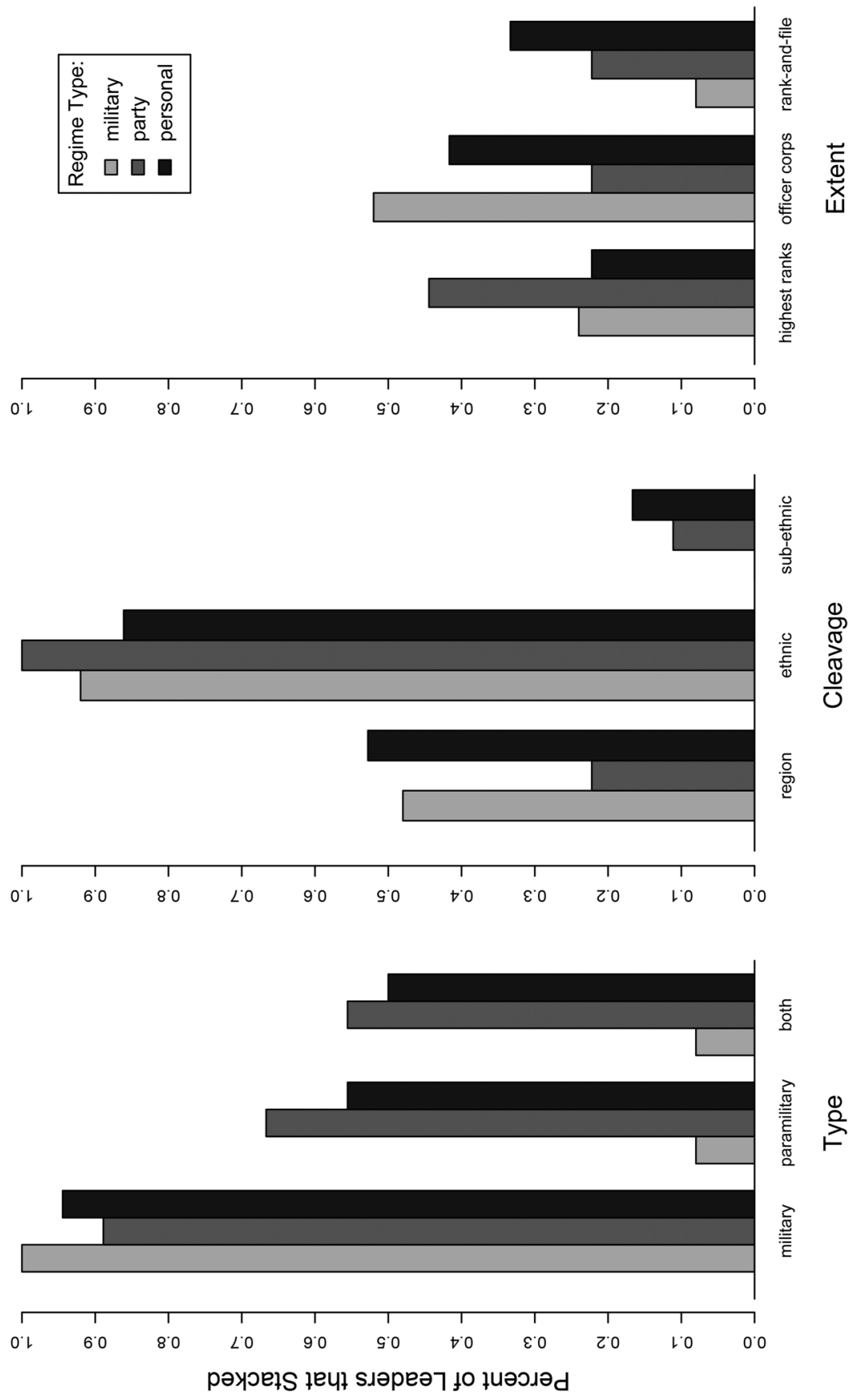

Figure 5. How different autocracies ethnically stack. 
22.2-24.0\%). Military regimes, on the other hand, tend to stack the entire officer corps $(52.0 \%)$ and rarely manipulate the rank-and-file $(8.0 \%)$. While personalist dictators also prefer stacking the whole officer corps $(41.7 \%)$, they are the most likely to manipulate ethnicity down to the rank-and-file (33.3\% vs. $22.2 \%$ of single-party autocracies).

\section{Conclusion}

ESAD provides comprehensive data on ethnic stacking practices across Africa, including whether stacking occurs in paramilitaries vs. militaries, how far down the command hierarchy it extends, and the ascriptive cleavages shaping it. Somewhat surprisingly, only $33.3 \%$ of African leaders have stacked their security institutions, reflecting both the decline in ethnic stacking with democratization and the fact that ethnicity has never been a driving force in the politics of many African countries. Indeed, the descriptive data presented throughout this article demonstrate the wide variance in ethnic stacking practices over both time and space and across regime types.

ESAD enables better statistical analyses of African militaries and their behavior, while also providing a bank of narratives and sources for case study selection. To highlight one example of the data's potential uses, the negative correlation between democratization and ethnic stacking suggests an important relationship. Could we better understand successful democratic consolidation by examining the temporal sequencing between de-stacking African militaries, liberalizing reforms, and holding competitive elections?

ESAD could also meaningfully contribute to the growing literature on autocracy by facilitating deeper investigations of how dictators design coercive institutions. Do the particular threats a leader faces when gaining power shape whether they ethnically stack, counterbalance, or rely on other tools of power consolidation? While ethnic stacking appears to lengthen leader tenure, how effective is this strategy vs. other means of staving off coups, mass protests, and other threats to dictatorial power? Does autocratic institutionalization, whether by party creation or elite power-sharing, enable dictators to include ethnic rivals and avoid stacking? What long-term impacts might such inclusion entail for sub-national economic development, attitudes toward government, and rebellion?

Alternatively, ESAD could be employed by civil war experts to better understand evolving dynamics between the state and insurgents. Does fighting against ethnically-based rebel movements lead state militaries to become more ethnically exclusive over time? Are ethnically stacked military and paramilitary units more likely to commit repression and other atrocities against civilian populations? Do ethnically stacked armies make peace negotiations more difficult, prolonging war? Are the resulting peace agreements more fragile as ethnically stacked militaries struggle to diversify themselves and integrate former rebels?

Ethnic stacking has been a widespread and important practice within African militaries, from the time of decolonization to the present. Conditioning military loyalty on shared ethnicity has profound consequences for a wide range of social and political processes-including coups, authoritarian power consolidation, repression, mass protests, democratization, rebellion, peace building, military cohesion, and combat effectiveness, among many more. By providing comprehensive data on this fundamental pillar of security force construction, it is my hope that ESAD will facilitate a much richer empirical analysis of African politics.

\section{Acknowledgments}

I would like to thank Sean Paul Ashley, Catherine Boone, Adam Casey, Erica De Bruin, Joan Riquart-Huguet, Jun Koga Sudduth, and Henning Tamm for their immensely helpful feedback on prior drafts, as well as my 
anonymous reviewers. I would also like to thank the participants of the St. Andrews Staff \& $\mathrm{PhD}$ Research Workshop and my 2019 APSA panel for their comments. I owe a deep debt of gratitude to all of the research assistants who worked on this project: Liam Arne, Joseph Baker, Olivia Chartier, Gillian Davies, Nathan Denby, Jonathan Gregory, Junyuan Rao, Peder Stampe, Haley Tanner, and Eileen Waters.

\section{Declaration of conflicting interests}

The author declared no potential conflicts of interest with respect to the research, authorship, and/or publication of this article.

\section{Funding}

The author disclosed receipt of the following financial support for the research, authorship, and/or publication of this article: this work was supported by the British Academy (grant number SG171429).

\section{ORCID iD}

Kristen Harkness (D) https://orcid.org/0000-0001-5882-3745

\section{Notes}

1. Johnson et al. (2019) are in the process of expanding this effort to African militaries. Chandra and Wilkinson (2008) also began developing a measure of "ethnic balance" that compares ethnic diversity within the military with country-level diversity, thus capturing the relative degree to which the military reflects society. However, this project has not been completed or published.

2. ESAD builds on Harkness (2018), who collected partial data on ethnic stacking in the decolonization and democratization periods. Without broader coverage beyond these two discrete historical eras, however, the data cannot be included in most statistical analyses and remains of fairly limited use to other scholars.

3. Of these five countries, the prior leaders of Egypt and Ethiopia had recruited diverse militaries while those of Liberia, South Africa, and Zimbabwe (Rhodesia) had ruled over highly ethnically/racially stratified systems of government and had extensively ethnically stacked the military.

4. A team of research assistants helped collect information for the narratives. They were tasked to search for information on both regular military and paramilitary units. They were also trained to search for both confirmatory evidence - ethnic preference or discrimination in recruitment, promotion, and retention practices —and disconfirmatory evidence-including practices that discriminate on grounds other than ethnicity (most importantly class) as well as non-discriminatory, inclusive, and merit-based practices.

5. Archives consulted include the National Archives of the UK (Kew), the French Colonial Archives (Aix-en-Provence), the French Military Archives (Vincennes), the US National Archives II (College Park), the online declassified records of the CIA, the National Archives of Senegal (Dakar), and the Kenya National Archives (Nairobi).

6. Data drawn from Harkness (2018), Online Supplementary Material.

7. Democracy rates calculated using the Geddes, Wright \& Frantz regime type data (2014). Ethnic stacking trends are calculated using the country-year data and exclude ethnically homogeneous countries and missing observations.

8. Owing to the mix of bivariate and continuous variables, correlations were calculated using appropriate logit or OLS models.

9. Drawn from the Ethnic Power Relations (EPR) 2021 dataset (Vogt et al., 2015), which includes measures for both ethnic group access to political power and the size of the group as a percentage of the total population. For each country-year, the group sizes were summed for all groups coded as included in executive power: the categories "monopoly", "dominant", "senior partner", and "junior partner". A leader-spell measure was then constructed by averaging the country-year inclusion score over their tenure. 
10. A bivariate indicator drawn from DeBruin (2021), coded 1 if the leader possessed at least one counterbalancing unit during their tenure and 0 otherwise.

11. An index constructed from three measures of personalism in civilian institutions drawn from Geddes et al. (2018): (1) whether the leader created a new ruling party; (2) whether the leader choose or vetoed members of their party's executive committee; and (3) whether the party acted as a rubber stamp for policy and personnel decisions made by the leader. A leader-spell index score was calculated by summing the total points over the leader's tenure and then averaging by both the number of variables and the length of tenure.

12. An index based on six annual dichotomous measures of regime institutionalization from Meng (2020): (1) whether the constitution contained a clear succession rule; (2) whether the constitution provided for term limits; (3) whether a vice-president was appointed; (4) whether the same-vice president was appointed as the previous year; (5) whether a defense minister was appointed; and (6) whether the same defense minister was appointed as the previous year. Calculated in the same way as the civlian personalism index.

13. See the Ethnic Power Relations Core Dataset Codebook, Version 2021: 5 at https://icr.ethz.ch/data/epr/ core/EPR_2021_Codebook_EPR.pdf, accessed 10 July 2021.

14. King Idris employed every tool in the ethnic stacking toolbox: relying on regional, ethnic, and sub-ethnic identities to stack both his paramilitary and the regular military, down to the rank-and-file (Keegan, 1983: 366-375).

\section{References}

Adekson, JB (1976) Army in a multi-ethnic society: The case of nkrumahs Ghana. Armed Forces and Society 2(2): 251-272.

Albrecht, H (2015) Does coup-proofing work? Political-military relations in authoritarian regimes amid the Arab uprisings. Mediterranean Politics 20(1): 36-54.

Baynham, S (1985) Divide et impera: Civilian control of the military in Ghana's second and third republics. The Journal of Modern African Studies 23(4): 623-642.

Bellin, E (2012) Reconsidering the robustness of authoritarianism in the Middle East: Lessons from the Arab Spring. Comparative Politics 44(2): 127-149.

Brett, EA (1995) Neutralising the Use of Force in Uganda: The Role of the Military in Politics. The Journal of Modern African Studies 33(1): 129-152.

Bratton, M \& van de Walle, N (1997) Democratic Experiments in Africa. Cambridge: Cambridge University Press.

Byrnes, RM (1992) Uganda: A country Study. Washington, D.C.: Federal Research Division, Library of Congress. Available at: https://www.loc.gov/item/92000513/ (accessed April 20, 2019).

Carbone, GM (2008) No-Party Democracy: Ugandan Politics in Comparative Perspective. Boulder: Lynne Rienner.

Cawthra, G (2003) Security transformation in post-apartheid South Africa. In: G Cawthra \& R Luckham (eds) Governing Insecurity: Democratic Control of Military and Security Establishments in Transitional Democracies. London: Zed Books, 31-56.

Cederman, LE, Wimmer, A \& Min, B (2010) Why Do ethnic groups rebel?: New data and analysis. World Politics 62(1): 87-119.

Cederman, LE, Gleditsch, KS \& Buhaug, H (2013) Inequality, Grievances, and Civil War. Cambridge: Cambridge University Press.

Chandra, K (2012) Constructivist Theories of Ethnic Politics. Oxford: Oxford University Press.

Chandra, K \& Wilkinson, S (2008) Measuring the effect of 'ethnicity'. Comparative Political Studies 41(4/5): $515-563$.

Chirambo, R (2004) 'Operation Bwezani': The army, political change, and Dr Banda's hegemony in Malawi. Nordic Journal of African Studies 13(2): 146-163.

Colleo, T (1991) Angola: A Country Study. Washington, DC: Federal Research Division, Library of Congress. Available at: https://www.loc.gov/item/90003244/ (accessed April 20, 2019). 
Coppedge, M, Gerring, J, Knutsen, CH, et al. (2019) V-Dem [country-year/country-date] dataset v9. Varieties of Democracy (V-Dem) Project. Available at: https://doi.org/10.23696/vdemcy19 (accessed October 7, 2021).

Cox, TS (1976) Civil-Military Relations in Sierra Leone: A Case Study of African Soldiers in Politics. Cambridge, MA: Harvard University Press.

Daley, P (2006) Ethnicity and political violence in Africa: The challenge to the Burundi state. Political Geography 25(6): 657-679.

Davies, VAB (2000) Sierra Leone: Ironic tragedy. Journal of African Economies 9(3): 349-369.

DeBruin, E (2021) Mapping coercive institutions: A new data set of state security forces, 1960-2010. Journal of Peace Research. 58(2): 315-325.

DeBruin, E (2020) How to Prevent Coups D'État: Counterbalancing and Regime Survival. Ithaca, NY: Cornell University Press.

Decalo, S (1973) Regionalism, politics, and the military in dahomey. The Journal of Developing Areas 7(3): 449-478.

Decalo, S (1989) Modalities of civil-military stability in Africa. Journal of Modern African Studies 27(4): 547-578.

Decalo, S (1998) Civil-Military Relations in Africa. Gainesville, FL: Florida Academic Press.

Enloe, CH (1975) The military uses of ethnicity. Millenium 4(3): 220-233.

Enloe, CH (1980) Ethnic Soldiers: State Security in Divided Societies. Athens, GA: University of Georgia Press.

Geddes, B, Wright, J \& Frantz, E (2014) Autocratic breakdown and regime transitions: A New dataset. Perspectives on Politics 12(2): 313-331.

Geddes, B, Wright, J \& Frantz, E (2018) How Dictatorships Work: Power, Personalization, and Collapse. Cambridge: Cambridge University Press.

Goemans, HE, Gleditsch, KS \& Chiozza, G (2009) Introducing Archigos: A Dataset of Political Leaders. Journal of Peace Research 46(2): 269-183. Data available at https://www.rochester.edu/college/faculty/ hgoemans/data.htm (accessed October 7, 2021).

Goldsworthy, D (1981) Civilian control of the military in black Africa. African Affairs 80(318): 49-74.

Greitens, SC (2016) Dictators and Their Secret Police: Coercive Institutions and State Violence. Cambridge: Cambridge University Press.

Harkness, KA (2015) Security assistance in Africa: The case for more. Parameters 45(2): 13-24.

Harkness, KA (2016) The ethnic army and the state: Explaining coup traps and the difficulties of democratization in Africa. Journal of Conflict Resolution 60(4): 587-616.

Harkness, KA (2017) Military loyalty and the failure of democratization in Africa: How ethnic armies shape the capacity of presidents to defy term limits. Democratization 24(5): 801-818.

Harkness, KA (2018) When Soldiers Rebel: Ethnic Armies and Political Instability in Africa. Cambridge: Cambridge University Press.

Hassan, M (2017) The strategic shuffle: Ethnic geography, the internal security apparatus, and elections in Kenya. American Journal of Political Science 61(2): 382-395.

Hornsby, C (2013) Kenya: A History Since Independence. London: I.B. Tauris.

Horowitz, DL (1985) Ethnic Groups in Conflict. Berkeley, CA: University of California Press.

Johnson, JJ (2015) The Role of the Military in Underdeveloped Countries. Princeton, NJ: Princeton University Press.

Johnson, PL \& Thurber, C (2020) The security force ethnicity (SFE) project: Introducing a new dataset. Conflict Management and Peace Science. 37(1): 106-129.

Johnson, PL, McLauchlin, T, Morency-Laflamme, J, et al. (2019) Ethnicity and defection during uprisings from below: New data and analysis. Paper presented at the annual meeting for the International Studies Association, Toronto, Canada, 27-30 March.

Jowell, M (2014) Cohesion through socialization: Liberation, tradition and modernity in the forging of the Rwanda defense force (RDF). Journal of East African Studies 8(2): 278-293.

Kagoro, J (2016) Competitive Authoritarianism in Uganda: The Not So Hidden Hand of the Military. Comparative Governance and Politics Special Issue 6: 155-172.

Kandeh, JD (1992) Politicization of ethnic identities in Sierra Leone. African Studies Review 35(1): 81-99.

Keegan, J (1983) World Armies. Detroit, MI: Gale Research Company. 
Keesings: World News Archive (1971) President Obote Overthrown by Military Coup (February): volume 17. Lemarchand, R (1989) The killing fields revisited. Issue: A Journal of Opinion 18(1): 22-28.

Lieberman, E (2010) Bridging the qualitative-quantitative divide: Best practices in the development of historically oriented replication databases. Annual Review of Political Science 13: 37-59.

Lindemann, S (2011) The Ethnic Politics of Coup Avoidance: Evidence from Zambia and Uganda. Africa Spectrum 46(2): 3-41.

Lyall, J (2020) Divided Armies: Inequality and Battlefield Performance in Modern War. Princeton, NJ: Princeton University Press.

Margulies, M (2018) The politics of military reform: Explaining changes in military recruitment. Paper presented at the annual meeting for the International Studies Association, Toronto, Canada, 27-30 March.

Mashike, L (2007) 'Blacks can win everything, but the army': The 'transformation' of the South African military between 1994-2004. Journal of Southern African Studies 33(3): 601-618.

McLauchlin, T (2010) Loyalty strategies and military defection in rebellion. Comparative Politics 42(3): 333-350.

McLauchlin, T \& Morency-Laflamme, J (2020) The efficacy of ethnic stacking: Military defections during uprisings in Africa. Journal of Global Security Studies 5(4): 695-702.

Meng, A (2020) Constraining Dictatorship: From Personalized Rule to Institutionalized Regimes. Cambridge: Cambridge University Press.

Minorities at Risk (2009) Minorities at Risk Dataset. Available at http://www.cidcm.umd.edu/mar (accessed August 1, 2016).

Morency-Laflamme, J (2018) A question of trust: Military defection during regime crises in Benin and Togo. Democratization 25(3): 464-480.

Mwakikagile, G (2009) Ethnicity and National Identity in Uganda: The Land and Its People. Dar-es-Salaam: New Africa Press.

N'Diaye, B (2001) The Challenge of Institutionalizing Civilian Control: Botswana, Ivory Coast, and Kenya in Comparative Perspective. Oxford: Lexington Books.

N'Diaye, B (2005) Not a miracle after all. Côte d'Ivoire's downfall: Flawed civil-military relations and missed opportunities. Scientia Militaria (South African Journal of Military Studies) 33(1): 89-118.

Ngaruko, F \& Nkurunziza, JD (2000) An economic interpretation of conflict in Burundi. Journal of African Economies 9(3): 370-409.

Omara-Otunnu, A (1987). Politics and the Military in Uganda, 1890-1985. New York: St. Martin's Press.

Pilster, U \& Böhmelt, T (2011) Coup-proofing and military effectiveness in interstate wars, 1967-99. Conflict Management and Peace Science 28(4): 331-350.

Preston, R (1997) Integrating fighters after war: Reflections on the Namibian experience. Journal of Southern African Studies 23(3): 453-472.

Ravenhill, FJ (1974) Military Rule in Uganda: The Politics of Survival. African Studies Review 17(1): 229260.

Ray, S (2012) The nonmartial origins of the 'martial races': Ethnicity and military service in ex-British colonies. Armed Forces \& Society 39(3): 560-575.

Robinson, C (2016) Revisiting the rise and fall of the Somali armed forces, 1960-2012. Defense \& Security Analysis 32(2): 237-252.

Roessler, P (2011) The enemy within: Personal rule, coups, and civil War in Africa. World Politics 62(2): $300-346$.

Roessler, P (2016). Ethnic Politics and State Power in Africa: The Logic of the Coup-Civil War Trap. Cambridge: Cambridge University Press.

Stubbs, T (2015) Ethnopolitics and the military in Kenya. In: DG Zirker (ed.) Forging Military Identity in Culturally Pluralistic Societies. Lanham, MD: Lexington Books, pp. 69-88.

Sudduth, JK (2017) Strategic logic of elite purges in dictatorships. Comparative Political Studies 50(13): $1768-1801$.

Sudduth, JK (2021) Purging militaries: Introducing the Military Purges in Dictatorships (MPD) dataset. Journal of Peace Research 58(4): 870-880.

Svolik, MW (2012a) Contracting on violence: The moral hazard in authoritarian repression and military intervention in politics. Journal of Conflict Resolution 57(5): 765-794. 
Svolik, MW (2012b) The Politics of Authoritarian Rule. Cambridge: Cambridge University Press.

Talmadge, C (2015) The Dictator's Army: Battlefield Effectiveness in Authoritarian Regimes. Ithaca, NY: Cornell University Press.

Tangri, R \& Mwenda, AM (2015) President Museveni and the Politics of Presidential Tenure in Uganda. Journal of Contemporary African Studies. 28(1): 31-49.

Tindigarukayo, JK (1988) Uganda, 1979-85: Leadership in Transition. The Journal of Modern African Studies 26(4): 607-622.

Uvin, P (1999) Ethnicity and power in Burundi and Rwanda: Different paths to mass violence. Comparative Politics 31(3): 253-271.

Vines, A (2013) Renamo's rise and decline: The politics of reintegration in Mozambique. International Peacekeeping 20(3): 375-393.

Vogt, M, Bormann, NC, Rüegger, S, et al. (2015) Integrating data on ethnicity, geography, and conflict: The ethnic power relations dataset family. Journal of Conflict Resolution 59(7): 1327-1342.

White, PB (2017) Crises and crisis generations: The long-term impact of international crises on military political participation. Security Studies 26(4): 575-605.

Wilkinson, SI (2015) Army and Nation: The Military and Indian Democracy Since Independence. Cambridge: Harvard University Press.

Wimmer, A, Cederman, LE \& Min, B (2009) Ethnic politics and armed conflict: A configurational analysis of a New global data Set. American Sociological Review 74(2): 316-337.

Young, C (1994) The African Colonial State in Comparative Perspective. New Haven, CT: Yale University Press.

\section{Appendix: Sample Narratives for Uganda}

\section{Obote (09//0//962-25/0///97I): Lango}

Ethnic Stacking = 1, ES_mil = 1, ES_paramil = 1, Extent =3, Cleavages = region, ethnic

After sidelining Mutesa, Obote dismissed 25 Baganda officers, court-martialed and dismissed educated southern officers in general, and increased recruitment from the North. Ethnicity became the primary basis of recruitment and promotion. Divisions began emerging between the northern officers by 1968. After two assassination attempts on his life, and with growing suspicion of his protégé Idi Amin, Obote then began recruiting more Acholi and Lango into the military in order to counter the larger number of troops from Amin's home district (West Nile). Obote also recruited the General Service Unit exclusively from the Acholi and Lango, mainly from his native Akororo district. Amin claimed that, prior to his coup, a secret meeting was held between the Minister of the Interior, the Army Chief-of-Staff, the Inspector-General of the Police and other senior officers in which it was decided that the army would be taken over by troops from the Lango and Acholi tribes (who constituted $75 \%$ of the army). These troops would be used to disarm all other officers and enlisted men. Sources: Brett (1995: 136), Byrnes (1992), Horowitz (1985: 455 \& 466), Keesings (1971), Minorities at Risk (2009) and Ravenhill (1974: 240).

\section{Amin (25/0I//97I-I I/04//979): Kakwa}

Ethnic Stacking = 1, ES_mil = 1, ES_paramil =0, Extent = 3, Cleavages = ethnic

After Amin's coup, a drawn out fight occurred within the military to subdue factions loyal to Obote. Thousands of Acholi and Lango soldiers were purged and executed, decimating the officer corps. Rank-and-file soldiers were also imprisoned and purged. Mass desertions followed. By the end of 1972, only one-third of the military's pre-coup army remained. Amin then recruited 
10,000 new soldiers, with around 4000 drawn from southern Sudan's Anyanya rebels (essentially mercenaries) and the rest recruited predominantly from Amin's native West Nile district, especially "Nubians" and Kakwa. Sources: Brett (1995: 138-139), Minorities at Risk (2009) and Ravenhill (1974: 241).

\section{Yusuf Lule (I //04//979-20/6//979): Buganda}

Ethnic Stacking $=0$, ES_mil $=0$, ES_paramil $=0$, Extent $=0$, Cleavages $=$ none

Lule implemented a quota system for military recruitment, allotting spaces based on ethnicity. Each ethnic group had a number of recruits proportional to the percentage that ethnic group held in the country's population. Lule came from Buganda, the largest ethnic group. Lule's effort to reform recruitment was met with protest from smaller and more traditional areas for recruits, Acholi and Lango. Sources: Lindemann (2011a: 21) and Omara-Otunnu (1987).

\section{Binaisa (20/6//979-/2/05//980): Buganda}

Ethnic Stacking =0, ES_mil =0, ES_paramil =0, Extent $=0$, Cleavages $=$ none

Under Binaisa, both rank-and-file soldiers and officers tended to come from the districts of their former rebel leaders (Amin had been overthrown with Tanzanian assistance): Ankole, Lango and Acholi. Sources: Tindigarukayo (1988: 612).

Muwanga (12/05/1980-17/12/1980): Buganda

Ethnic Stacking =0, ES_mil =0, ES_paramil =0, Extent $=0$, Cleavages $=$ none

Muwanga was only head of state for 10 days and thus could not change military recruitment practices. The army he inherited had little Baganda representation. Sources: Tindigarukayo (1988: 612).

\section{Obote (I 7//2//980-27/07//985): Langi}

Ethnic Stacking = 1, ES_mil = 1, ES_paramil = 0, Extent =3, Cleavages $=$ ethnic

Obote trusted Lango officers and favored them in promotions, especially to key command and control positions. By 1984 there was only one Acholi in a key military position, and he was about to retire. On the whole Lango and Acholi soldiers comprised $80 \%$ or more of the armed forces during this time. When Museveni took up arms against the government after Obote's election, most of the soldiers from western Uganda deserted. Sources: Lindemann (2011a: 21-22), Mwakikagile (2009), Omara-Otunnu (1987: 158) and Tindigarukayo (1988: 617).

\section{Okello (27/07//985-29/0 I//986): Acholi}

Ethnic Stacking = 1, ES_mil=1, ES_paramil =0, Extent $=3$, Cleavages $=$ ethnic

Acholi soldiers revolted against the Obote regime and seized power, fearing that they were being replaced at higher ranks while ordinary Acholi soldiers were being sent to the front lines to fight guerrillas. Five out of nine of the military ruling council were Acholi. Army officers and enlisted men were mainly Acholi. Many Lango in the government and army were removed. The Acholi and Lango alliance ended and ethnic violence increased. Sources: Mwakikagile (2009: 224) and Tindigarukayo (1988: 617-619). 


\section{Museveni (29/0I//986 - present): Bahima/Banyankole}

Ethnic Stacking =1, ES_mil=1, ES_paramil = 1, Extent =1, Cleavages = ethnic, sub-ethnic

Top positions in the military are dominated by the Bahima sub-group of the Banyankole. Ten of 15 lifetime members of the Defense Forces Council and five of six of the military High Command are Banyankole. During the guerrilla war, the officer corps and commanders came to be dominated by Banyakole while the foot soldiers/rank-and-file were largely comprised of Baganda. This has persisted since Museveni took power. The presidential guard are also largely Bahima. Sources: Carbone (2008: 46-47), Kagoro (2016: 168), Lindemann (2011a: 22) and Tangri and Mwenda (2010: 44). 